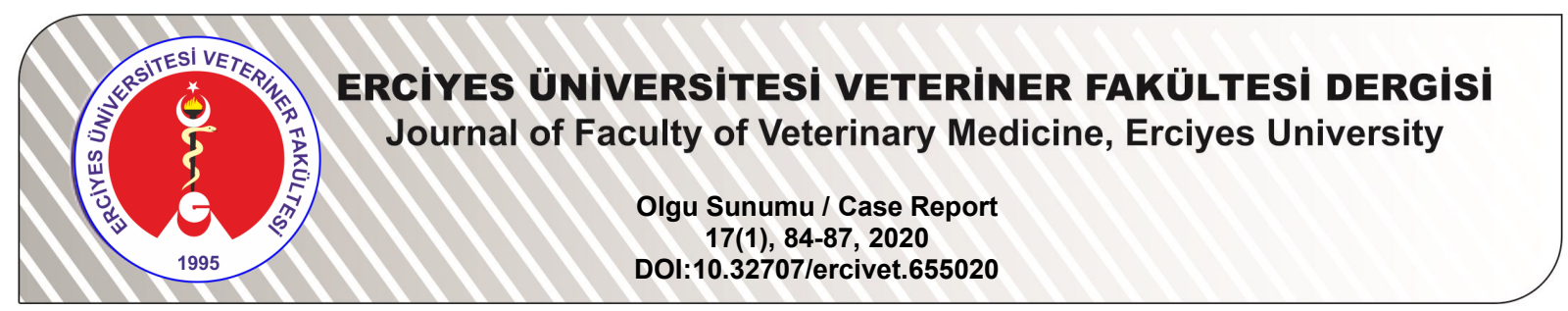

Squamous Cell Carcinoma of the Third Eyelid Membrane in an African Grey Parrot (Psittacus erithacus)

\author{
Aynur DEMiR ${ }^{1}$, Kübra GERBAGA ÖZSEMIR ${ }^{1}$ Özge ERDOĞAN BAMAÇ² \\ ${ }^{1}$ Istanbul Cerrahpaşa University, Faculty of Veterinary Medicine, Department of Surgery, İstanbul-TURKEY \\ ${ }^{2}$ Istanbul Cerrahpaşa University, Faculty of Veterinary Medicine, Department of Pathology, İstanbul-TURKEY
}

\begin{abstract}
Corresponding author: Aynur DEMiR; E-mail: aynurdemir_1903@hotmail.com; ORCID: 0000-0001-2345-6789
How to cite: Demir A, Gerbaga Özsemir K, Erdoğan Bamaç Ö. Squamous cell carcinoma of the third eyelid membrane in an African grey parrot (Psittacus erithacus). Erciyes Üniv Vet Fak Derg 2020;17(1): 84-87.
\end{abstract}

Summary: Squamous cell carcinoma (SCC) of the third eyelid membrane (also known as the nictitating membrane) was diagnosed in a 34-year-old African grey parrot (Psittacus erithacus) that was presented to the clinics of our faculty for unilateral periorbital swelling, blepharospasm, severely bleeding of 2 months duration. A large, hard, yellow mass on the bulbar surface of the third eyelid membrane that was attached to the ventro-medial quadrant of the bulbar conjunctiva was identified under general anesthesia. Surgical removal of the mass was performed but the bird died just after the operation. The left globe with adnexal tissues and the body of bird were submitted for histopathological examination. The dimensions of the solitary mass were $0.8 \times 1 \mathrm{~cm}$ and the histopathological examination revealed SCC. There was no evidence of metastasis in the globe and other organs.

Key words: African grey parrot, nictitating membrane, Psittacus erithacus, squamous cell carcinoma, third eyelid membrane

\title{
Bir Afrika Gri Papağanında Üçüncü Göz Kapağının Skuamöz Hücreli Karsinomu
}

Özet: İki aydır süren tek taraflı periorbital şişlik, blefarospazm ve şiddetli kanama şikayetiyle fakülte kliniklerine getirilen 34 yaşlı bir Afrika gri papağanında (Psittacus erithacus), üçüncü göz kapağının (niktitan membran olarak da bilinen) skuamöz hücreli karsinomu (SCC) teşhis edildi. Genel anestezi altında, üçüncü göz kapağı membranının bulbar yüzeyinde, göz küresinin bulbar konjunktivasının ventromedial kadranına bağlı büyük, sert, sarı bir kitle tespit edildi. Kitle cerrahi olarak eksize edildi, ancak operasyondan hemen sonra kuş öldü. Kuş ve sol göz küresi adneksal yapılarıyla birlikte histopatolojik incelemeye gönderildi. Kitle $0.8 \times 1 \mathrm{~cm}$ boyutlarındaydı ve histopatolojik incelemede SCC olduğu belirlendi. Göz küresi ve vücudun diğer organlarında metastaz görülmedi.

Anahtar kelimeler: Afrika gri papağanı, niktitan membran, Psittacus erithacus, skuamöz hücre karsinomu, üçüncü göz kapağı

\section{Introduction}

The nictitating membrane has a transparent structure which is presented in some animals that allows the eye to be moisturized and protection from any dust and debris (Stibbe, 1928; Maggs et al., 2013; Jochems and Phillips, 2015; Klećkowska-Nawrot et al., 2016). Unlike the upper and lower eyelids, the nictitating membrane moves across the eyeball horizontally and covers almost the entire eyeball and does not obstruct vision (Sivak et al., 1978; Jochems and Phillips, 2015; Klećkowska-Nawrot et al., 2016). Birds can actively control their nictitating membrane owing to muscle control. It begins at the inside corner of the eye closest to the beak and moves across to the outside corner (Kern et al., 1996; Bayon et al. 2007; Maggs et al., 2013). This structure also has many disorders like other organs that affect the appearance and functions. These diseases which impair the structure and functions of the eyelids are; infection, trauma, neoplasia and degeneration. Although other

Geliş Tarihi/Submission Date : 18.03.2019 Kabul Tarihi/Accepted Date : 16.07 .2019 diseases are common, neoplasms are very rare among these diseases. Chondrosarcoma, myoid cystoma, Marek's disease, lymphoma, hibernoma, xanthoma, squamous cell carcinoma are reported tumors of the third eyelid (Sivak et al., 1978). SCC has been reported rarely in parrots although it is common in budgerigars. Anatomic locations of SCC are tongue, pharynx, gastrointestinal system, uropygial gland, upper weak, head, eyelid, neck, wings and leg's skin. As in other species, SCC has a very invasive effect in birds but it is slow to metastasize (Diaz-Figueroa et al., 2006).

In our country, no studies have been reported indicating the occurrence of this cancer in the third eyelid of the birds. In this case report, the clinical and histopathological findings of SCC that was detected in the third eyelid of an African grey parrot is evaluated.

\section{Case}

A 34-year-old African grey parrot (Psittacus erithacus) of unknown sex was presented to the Surgical Department of the Veterinary Hospital of Istanbul University-Cerrahpaşa with a complaint of unilateral 
periorbital swelling, and blepharospasm. The owner declared that the bird had been constantly scratching the eye and causing bleeding for 2 weeks. No diagnostic tests had been performed by the referring veterinaria. The bird had been previously treated with enrofloxacin for a week. According to the owner, initial treatment with enrofloxacin had not been effective, hemorrhage of the left eye had not resolved and periorbital swelling was observed. The bird's diet consisted of vegetables, fruits and commercial pelleted diet.

On physical examination, the weight of the bird was $410 \mathrm{~g}$. There were no clinical findings of respiratory and urinary diseases. Ophthalmic examination revealed unilateral slight periorbital swelling and the third eyelid was partially prolapsed and it's surface was covered by the hematoma and exudates. The anterior segment of the same eye was not seen because of the exudates that had sticked to the ocular surface. The right eye and the other physical examination findings were normal.

A blood sample was collected and submitted for a complete blood cell (CBC) count and plasma biochemical analysis. Results were unremarkable with the exception of increased activities of creatine kinase (904 U/L; reference range, 123-875 U/L) and bile acids (524 Imol/L; reference range, $6-35 \mathrm{Imol} / \mathrm{L})$.

Initial empirical treatment consisted of topical $0.3 \%$ ofloxacin (Exocin ${ }^{\circledR}$, Abdi Ibrahim, Turkey) three times daily, artificial tears (Tears Natural free ${ }^{\circledR}$, Alcon, Turkey) three times daily and $1 \%$ fusidic acid hemihidrat (Fucithalmic $^{\circledR}$ gel, Abdi İbrahim, Turkey) two times daily. The patient received oral meloxicam $0.5 \mathrm{mg} / \mathrm{ml}$ (Metacam ${ }^{\circledR}$, Boehringer, $0.2 \mathrm{mg} / \mathrm{kg} / 24 \mathrm{~h}$ ) and amoxicilin sodium-clavulanic acid (125 mg/kg/PO q12h; Amoklavin suspansion ${ }^{\circledR}$, Turkey). Following several days of treatment, no clinical improvement of ocular signs was observed. The hemorrhagic exudates were removed but the third eyelid was hiperemic and totally prolapsed, its motility was relatively impeded (Figure 1). The left eye was exophthalmic. Almost every day extensive bleeding was occured by bird's self-trauma. It was difficult to make an inspection of ocular and internal surface of the third eyelid because of the bird's reactivity.

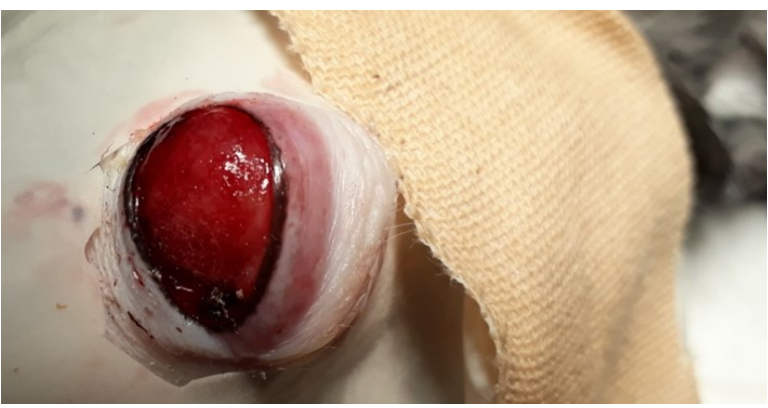

Figure 1. Hyperemic third eyelid membrane
Detailed eye examination under general anesthesia was performed for abnormal tissue biopsy and appropriate palliative treatment.

The bird was induced with $2 \%$ isoflurane administered via modified glove mask (Figure 2). On detailed eye examination under anesthesia, yellow-pink, multilobular, hard mass on the bulbar surface of the left third eyelid membrane was detected which was attached to the ventral portion of the bulbar conjunctiva of the globe. Hence, it was decided to remove the globe with the adnexa.

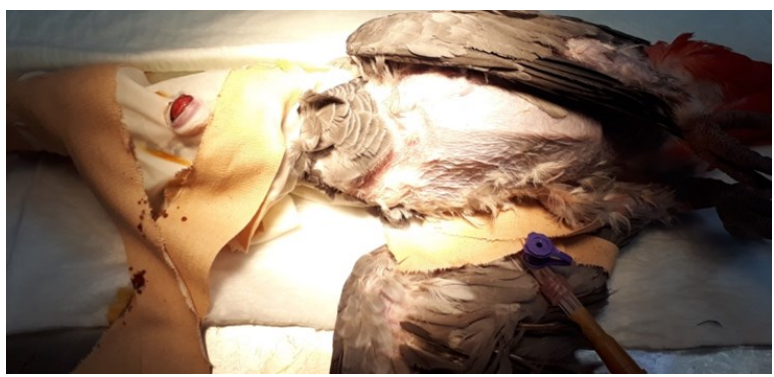

Figure 2. Isoflurane administered via modified glove mask

For treatment $5 \%$ dextrose lactate ringer was administered intravenously and preoperative butorphanol (Butamidor $^{\circledR}$, Richter Pharma AG, Austria) was used subcutaneously.

The bird was placed in dorsal recumbency, the head was turned laterally to expose the left eye. Ocular surface was cleaned with a dilute solution of $0.05 \%$ betadine. Periocular surface was painted with povidone iodine solution. Except the operation area, the bird was covered with a sterile cover. To facilitate dissection, eyelids were closed with two simple separate suture before the incision. A circular skin incision was made parallel to the edge of the eyelids. Then, blunt dissection was performed between the skin and conjunctiva and the eyeball was removed by exenteration bulbi technique (Figure 3).

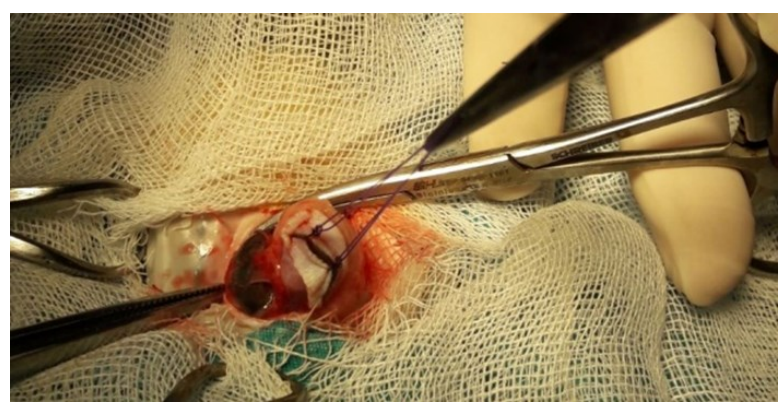

Figure 3. Removal of the eyeball with exenteration bulbi technique

In order to prevent bleeding, absorbable bleeding stopper sponge was placed into the orbita. After the bleeding control, the skin was closed with a simple 
separate suture with a $3 / 0$ monofilament polypropylene (Figure 4). After operation, the bird died. The mass with the left globe was removed by the exenteration bulbi method and submitted to Pathology Department (Figure 5).

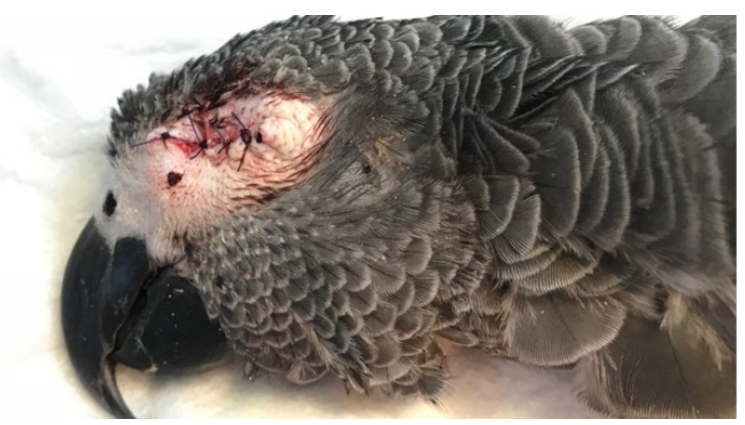

Figure 4. After removal of the mass, eyelids were closed with simple seperated suture

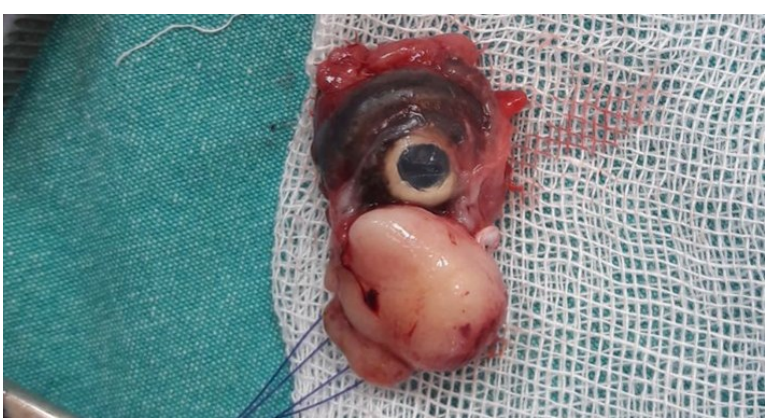

Figure 5. The mass adjacent to the globe

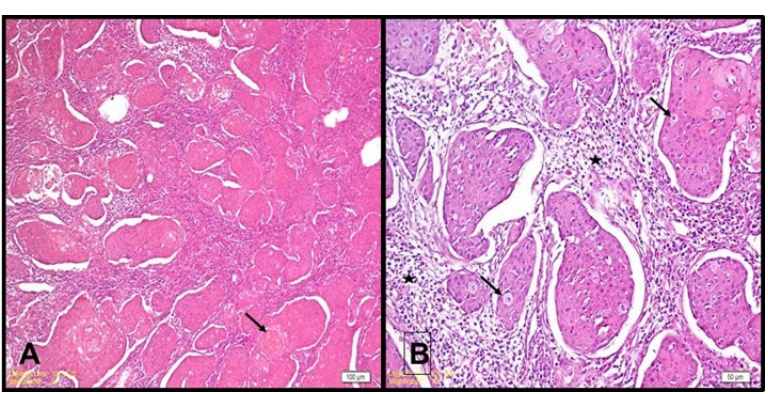

Figure 6. Various nests of malignant squamous cells. Keratin pearl in a nest (arrow) H\&E (A)

Bizarre squamous cells and mitotic figures (arrows), inflammatory cells mainly composed of heterophils, lymphocytes and plasma cells (star) (B)

Tissue samples were fixed in $10 \%$ buffered formalin, routinely processed, embedded in parffin. From paraffin block $5-\mu \mathrm{m}$ sections were cut and stained with haematoxylin and eosin (H\&E) and examined under light microscope. Histopathological diagnosis was squamous cell carcinoma of the third eyelid membrane. The tumor was compised of various nests of malignant squamous cells (Figure 6A, B). The keratin pearls were prominent. Bizarre squamous cells and mitotic figures were present. Inflammatory cells mainly composed of heterophil leukocytes, lymphocytes and plasma cells were observed.

\section{Discussion and Conclusion}

In all birds, the third eyelid membrane is a structure of the dorsal nasal portion of the conjunctival sac that is also composed of epithelial, muscle, connective and vascular tissue (Maggs et al., 2013; Jochems and Phillips, 2015; Klećkowska-Nawrot et al., 2016). Due to the muscular structure, it has the ability to move independently (Stibbe, 1928; Sivak et al., 1978). The internal surface of the eyelid is covered by columnar strafied epithelium while the external surface is composed of stratified squamous epithelium (Stibbe, 1928; Kern et al., 1996). The epithelium and vascular structure of the nictitating membrane engenders a predisposing cause for to the formation of malignant tumors like SCC. Malignant tumors of the third eyelid have been reported to be extremely rare in birds (Sivak et al., 1978). To the best of author's knowledge, this is the first case report of a SCC on the nictitating membrane in an African grey parrot in our country.

In human and most domestic species such as cats and dogs, SCC has been reported to be an extremely invasive but slow, metastatic, malignant, epithelial tumor of the squamous epithelium. The same is true for avian species (Diaz-Figueroa et al., 2006). Although this tumor is observed commonly in budgerigars, it has been reported rarely in Psittaciformes (DiazFigueroa et al., 2006; Pye et al., 2009). In birds, anatomic locations of this tumor is the globe, orbit, infraorbital sinus, tongue, pharynx, gastrointestinal system, uropygial gland, beak skin of the head, neck, eyelids, chest, wings and legs (Diaz-Figueroa et al., 2006; Pye et al., 2009).

SCC has been reported to occur widely in the nonpigmented eyelid epithelium, bulbar conjunctiva and third eyelid in animals which was exposed to the outdoors and sunlight (Rodriguez-Ramos Fernandez and Dubielzig, 2014). However, the exact etiology of this tumor is still not fully known. In this case, histopathological examination revealed that tumor cells were originated from conjunctival epithelial cells of the third eyelid membrane. In birds, the third eyelid does not have a nictitating gland unlike cats and dogs so it can be removed when necessary but it has to be considered that it is very important for birds that look for food underwater and flying at high speed (Sivak et al. 1978; Klećkowska-Nawrot et al., 2016).

Due to its invasiveness, early diagnosis and surgery of the squamous cell carcinoma is necessary and important for prognosis. Therapeutic options that have been included cryotheraphy, chemotheraphy with carboplastin, radiation theraphy with strontium90 (Sr-90), radioactive implants and photodynamic theraphy (Diaz-Figueroa et al., 2006; Ledwon et al. 2013). 
We believe that the surgical removal of the tumor was the only option in our case although the parrot could not survive after the operation and reporting this case will contibute valuable information to the veterinary literature since SCC of the third eyelid membrane is African Grey Parrots.

\section{References}

Bayon A, Almela RM, Talavera J. Avian ophthalmology. EJCAP 2007; 17 (3): 1-13.

Diaz-Figueroa O, Tully Jr TN, Williams J, Evans D. Squamous cell carcinoma of the infraorbital sinus with fungal tracheitis and ingluvitis in an adult Solomon eclectus parrot (Eclectus roratus solomonensis). J Avian Med Surg 2006; 20 (2): 113-9

Jochems $B$, Phillips $T$ E. Histological and ultrastructural studies on the conjunctiva of the barred owl (Strix varia). PloS one 2015; 10 (11): 119.

Kern TJ, Paul-Murphy J, Murphy CJ, Buyukmihci NC, Burling K, Miller PE, et al. Disorders of the third eyelid in birds: 17 cases. J Avian Med Surg 1996; 10 (1): 12-8.

Klećkowska-Nawrot J, Nowaczyk R, Goździewska -Harłajczuk K, Barzsscs K, Kowalczyk A, Lukaszevics ET. Light and electron microscopic study of the eyelids, conjunctiva-associated lymphoid tissue and lacrimal gland in Bilgorajska Goose (Anser anser). Anat Sci Int 2016; 91(1) : 7488

Ledwon A, Dolka B, Dolka I, Szeleszczuk P. Successive therapy of squamous cell carcinoma in African grey parrot. Med Weter 2013; 69 (05) :3047.

Maggs DJ, Miller PE, Ofri PE. Slatter's Fundamentals of Veterinary Ophthalmology. Maggs DJ. ed. In: Third Eyelid. Fifth edition. St. Louis, MO: Saunders Elsevier 2013; pp. 151-6.

Pye GW, Carpenter JW, Goggin JM, Bacmeister C. Metastatic squamous cell carcinoma in a salmon -crested cockatoo (Cacatua moluccensis). J Avian Med Surg 2009; 13(3): 192-200.

Rodriguez-Ramos Fernandez J, Dubielzig RR. Ocular and eyelid neoplasia in birds: 15 cases (1982-2011). Vet Ophthalmol 2014; 18(1): 1-6

Sivak JG, Bobier WR, Levy B. The refractive significance of the nictitating membrane of the bird eye. J Comp Physiol 1978; 125(4): 335-9.

Stibbe EP. A comparative study of the nictitating membrane of birds and mammals. J Anat 1928; 62 (2):159-76. 